Jurnal Ekonomika Regional Unimal, Volume 3 Nomor 1 April 2020

E-ISSN : 2615-126X

URL: http://ojs.unimal.ac.id/index.php/ekonomi_regional

\title{
Pengaruh Pajak Daerah, Retribusi Daerah dan Laba Badan Usaha Milik Daerah di (BUMD) Terhadap Pertumbuhan Ekonomi Kabupaten Aceh Utara
}

\author{
Muchsal Mina ${ }^{a^{*}}$, Ratna $^{\mathrm{b}^{*}}$ \\ * \\ Fakultas Ekonomi dan Bisnis Universitas Malikussaleh \\ a Corresponding author: muchsalmina1997@gmail.com \\ b ratnahus@yahoo.com
}

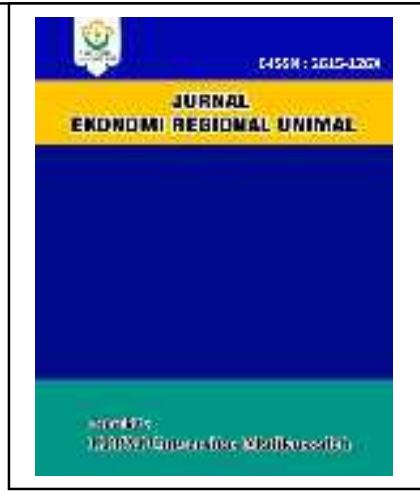

ARTICLE INFORMATION

Keyword : Regional Taxes, Regional Levies, Owned Enterprise Profits Regions, Economic Growth.
A B S T RA C T

This study aims to determine how much influence local taxes, regional levies and profits of regional-owned enterprises on economic growth in North Aceh Regency. The data used in this study is secondary data sourced from the North Aceh Central Bureau of Statistics 2005-2017. The data analysis method used in this study is multiple linear regression methods. With the help of Eviews 10 the results of the research partially show that regional taxes have a negative and significant effect on economic growth in North Aceh District. regional retribution does not affect and negatively affect economic growth in North Aceh Regency, and the profits of regionally owned enterprises have a positive and significant effect on economic growth in North Aceh District. The results of the tests carried out jointly are known that Regional Taxes, Regional Levies and profits of Regionally Owned Enterprises have a joint effect on Economic Growth in North Aceh Regency at 0.8133 (8133\%). 


\section{PENDAHULUAN}

Pembangunan ekonomi wilayah kabupaten/kota ialah awal dari pelaksanaan pembangunan, supaya daerah bisa lebih mengetahui potensi dan apa yang menjadi kebutuhan wilayahnya. Menurut Blakely dalam (Walewangko, 2017) pembangunan ekonomi wilayah yaitu proses pemerintah dan semua komponen masyarakat mengelola berbagai sumber daya yang dimiliki dan membentuk kerjasama untuk membuat lapangan kerja baru dan merangsang aktivitas ekonomi wilayah.

Desentralisasi atau otonomi daerah membuat daerah memiliki kewenangan yang lebih besar untuk mengatur berkaitan dengan rumah tangganya. Hal ini menuntun pemerintah wilayah agar bijak dalam memungut pajak dan retribusi di wilayah masing-masing. Selain itu pemerintah juga dituntun agar mampu mengalokasikan hasil pajak yang diterima sampai kepada penciptaan masyarakat yang adil, makmur, dan merata seperti Pancasila dan undang-undang dasar Negara Republik Indonesia tahun 1945.

Pertumbuhan ekonomi yang sangat menentukan ialah pajak, penerimaan pajak menyumbang pendapatan yang cukup besar, sehingga fungsi pajak cukup sentral. Disini perlu perhatian lebih dari pemerintah dalam meningkatkan pendapatan dari sektor pajak, melalui upaya-upaya pemberantasan mafia pajak. Pemerintah sekarang sedang memperbaiki sistem pungutan pajak disebabkan sistem lama masih memiliki kelemahankelemahan, perbaikan perlu dilaksanakan agar pendapatan negara dari sektor pajak tidak bocor, serta meningkatkan dimasa yang akan datang (Sunarto \& Sunyoto, 2016).

Pajak ialah sumber penerimaan yang dipakai oleh pemerintah untuk pembiayaan dalam menggerakkan roda pemerintah. Diwujudkan dengan kebijakan desentralisasi dalam mengelola wilayah itu sendiri seperti yang tercantum dalam kebijakan yang otonomi daerah.

Otonomi daerah di Indonesia diberlakukan pada tanggal 01 Januari 2001, dimana otonomi daerah mempercepat pemerintah berkreasi dan memutar otak mencari pendapatan wilayah agar mampu membiyai pengeluaran, serta dengan diberlakukannya otonomi daerah tersebut, pemerintah mnetapkan UndangUndang (UU) Nomor 32 Tahun 2004 sebagai pengganti UU Nomor 22 Tahun 1999 tentang pokok-pokok pemerintahan daerah (Kresnandra \& Ni Made, 2013).

Persentase realisasi pendapatan yang berasal dari pajak wilayah Kabuapten Aceh Utara terbesar diperoleh dari jenis pajak pajak penerangan jalan sebesar 47,66 persen. Sedangkan penerimaan pendapatan pajak daerah dari hotel dan restoran masih tidak memenuhi target. Pertumbuhan ekonomi juga dibayangi oleh retribusi wilayah tertentu (BPS, 2016).

Selain bersumber dari pajak daerah, pertumbuhan ekonomi juga dapat bersumber dari retribusi daerah. Retribusi merupakan pungutan yang dilakukan akibat dari pemberian jasa atau fasilitas oleh pemerintah secara langsung dan nyata pada pembayar. Dengan demikian, retribusi daerah juga mempunyai fungsi penting untuk peningkatan pertumbuhan ekonomi serta membiayai pengeluaran pemerintah daerah (Kusuma \& Wirawati, 2013).

Seperti halnya pajak dan retribusi daerah, Laba badan usaha milik daerah (BUMD) merupakan salah satu aspek pertumbuhan ekonomi, kemampuan perusahaan yang dikelola oleh pemerintah kabupaten setempat sehingga dari proses operasi perusahaan-perusahaan keuntungan yang dihasilkan menjadi pendorong pertumbuhan ekonomi wilayah tersebut.

Perusahaan daerah yang merupakan bentuk badan usaha yang layak untuk melaksanakan pengelolaan pasar dengan manajemen yang tepat dan profesional, mengingat perkembangan pasar dari tahun 
ke tahun terjadi peningkatan, sehingga mewadahi perkembangan pasar diperlukan sistem kerja untuk perusahaan, sedangkan tujuan normatif yang ingin dicapai meliputi peningkatan pendapatan dan peningkatan usaha (Kurniawan, 2010).

Dari penjelasan di atas diketahui pajak, retribusi daerah, dan hasil laba BUMD yaitu komponen penting pertumbuhan ekonomi. penulis juga menulis data pertumbuhan ekonomi, retribusi daerah, pajak daerah dan Laba BUMD didapatkan dari beberapa Intansi pemerintah ialah badan perencanaan pembangunan daerah (BAPPEDA) dan Badan Pusat Statistik (BPS) pada pertumbuhan ekonomi diliat dari sektor non migas pada tahun 2005 sampai tahun 2017 juga terjadinya fluktuasi yang masih dalam keadaan setabil.

Dari penjelasan mengenai pertumbuhan ekonomi non migas, pajak daerah dan retribusi daerah di Kabupaten Aceh Utara. Terdapat fenomena pada tahun 2010 pajak daerah ialah sebesar Rp 10.130.341.564 milyar meningkat dari tahun sebelumnya yang hanya sebesar Rp 8.197.328.980 milyar, seharusnya dengan meningkat nya penghasilan pajak daerah dapat meningkatkan pertumbuhan ekonomi. Akan tetapi yang terjadi disini pertumbuhan ekonomi malah mengalami penurunan yaitu sebesar 3.3 persen. Pada tahun yang sama retribusi daerah mengalami penurunan dari tahun sebelumnya yaitu sebesar $\mathrm{Rp}$ 4.161.057.496 milyar. Sedangkan laba BUMD juga mengalami permasalahan yang sama dengan pajak daerah, laba BUMD meningkat dari tahun sebelumnya yaitu sebesar Rp 9.380.576.665 milyar, akan tetapi peningkatan pada laba BUMD malah menurunkan pertumbuhan ekonomi, ini merupakan suatu fenomena yang terjadi di Aceh Utara seharusnya peningkatan laba BUMD dapat meningkatkan pertumbuhan ekonomi.

Pada tahun 2011 pajak daerah adalah sebesar Rp 7.253.679.916 milyar menurun dari tahun sebelumnya yaitu sebesar $\mathrm{Rp}$
10.130.341.564 milyar, akan tetapi pertumbuhan ekonomi nya malah meningkat yaitu sebesar 7.50 persen, hal ini tidak sesuai dengan persamaan yang menyatakan pada saat pajak daerah meningkat pertumbuhan ekonomi akan meningkat atau sebaliknya.

Pada tahun yang sama retribusi daerah meningkatan dari tahun sebelumnya adalah sebesar Rp 5.233.430.665 milyar, peningkatan retribusi daerah dapat memberikan kontribusi yang baik bagi pertumbuhan ekonomi yang juga ikut meningkat yaitu sebesar 7.50 persen. Prospek yang bagus juga terjadi pada laba BUMD mengalami peningkatan dari tahun sebelumnya yaitu sebesar $\mathrm{Rp}$ 12.618.795.363 milyar sehingga memberikan kontribusi yang bagus untuk pertumbuhan ekonomi.

Pada tahun 2012 pajak daerah adalah sebesar Rp 13.876.067.033 milyar meningkat dari tahun sebelumnya akan tetapi malah menyebabkan pertumbuhan ekonomi menurun. Hal yang sama juga terjadi pada retribusi daerah Aceh Utara yang mengalami peningkatan yaitu sebesar Rp 5.973.890.739 milyar, akan tetapi kenaikan pada retribusi daerah tidak diikuti oleh pertumbuhan ekonomi.

Sebaliknya laba BUMD malah mengalami penurunan dari tahun sebelumnya yaitu sebesar Rp 9.392.420.700 milyar, sehingga memberikan berdampak negative pertumbuhan ekonomi menurun dari tahun sebelumnya sebesar 5.38 persen. Dari data pada periode di atas menunjukkan fenomena (permasalahan-permasalahan) yang terjadi di Kabupaten Aceh Utara.

Dari penjelasan diatas menyatakan adanya permasalahan (fenomena) terjadi yaitu pada saat pajak daerah, retribusi daerah dan laba BUMD meningkat malah menyebabkan penurunan pertumbuhan ekonomi di Kabupaten Aceh Utara. Kondisi ini cukup bertentangan dengan teori yang menyatakan jika pajak, retribusi daerah dan laba BUMD meningkat maka menyebabkan peningkatan pertumbuhan 
ekonomi di Kabupaten Aceh Utara. Masalah ini perlu di teliti dikarenakan ketika pajak daerah, retribusi daerah dan laba BUMD terjadinya keadaan yang sangat memuaskan seharusnya bias meningkatkan pertumbuhan ekonomi yang sangat memuaskan, akan tetapi sebaliknya pertumbuhan ekonomi semakin terpuruk ketika ketiga penerimaan daerah nya mengalami keadaan yang memuaskan.

Dari latar belakang masalah tersebutkan sehingga munculnya niat serta keinginan penulis membenarkan yang telah di uraikan dengan melakukan penelitian yang berjudul "Pengaruh Pajak Daerah, Retribusi Daerah dan Laba Badan Usaha Milik Daerah (BUMD) Terhadap Pertumbuhan Ekonomi di Kabupaten Aceh Utara".

\section{Kajian Teoritis}

\section{Jumlah Penduduk Miskin}

Jumlah penduduk miskin merupakan jumlah sekelompok masyarakat yang tidak bisa memenuhi kebutuhan hidupnya baik kebutuhan primer, sekunder dan lain sebagainya, hal ini akan menyebabkan permasalahan lain yang terus terjadi salah satunya akan menyebabkan pengangguran di lingkungan masyarakat yang terus meningkat jumlahnya. Sebutan kemiskinan mencuat saat individu/kelompok orang tidak mampu memenuhi kebutuhan seharihari untuk meneruskan kelangsungan hidupnya.

Seperti penelitian yang dikerjakan oleh Jafar (2017). Hasil penelitian mengatakan bahwa kemiskinan berpengaruh negatif terhadap pertumbuhan ekonomi. Selanjutnya, penelitian yang dilakukan oleh Purnama (2018). Hasil telitian memberikan penjelasan pertumbuhan ekonomi berpengaruh negatif terhadap kemiskinan. Serta penelitian yang dilakukan oleh Retno (2017). Hasil penelitian mengatakan kemiskinan berpengaruh negatif terhadap pertumbuhan ekonomi.

\section{Pertumbuhan Ekonomi}

Pertumbuhan ekonomi ialah ukuran prestasi dari perkembangan suatu perekonomian dari suatu periode ke periode berikutnya dan juga dari satu periode ke periode lainnya kemampuan suatu negara untuk menghasilkan barang dan jasa akan meningkat yang akan dapat dipakai untuk mensejahterakan masyarakat.

Pertumbuhan ekonomi suatu negara diukur dari pengembangan produk domestik bruto riil yang dicapai oleh suatu negara, wilayah/daerah. Economic Growth ialah aktivitas dalam dunia ekonomi berefek pada barang dan jasa yang diproduksikan di masyarakat bertambah dan kemakmuran meningkat (Yanis, 2018).

Pertumbuhan ekonomi bisa dikatakan akibat dari kenaikan jumlah produksi suatu perekonomian dan diwujudkan dalam bentuk peningkatan pendapatan nasional. Perekonomian disebutkan tumbuh ketika jumlah balas jasa rill terhadap penggunaan faktor-faktor produksi pada tahun tertentu lebih besar dari pada tahun sebelumnya.

Pertumbuhan ekonomi harus mengarah pada standar hidup yang lebih tinggi nyata dan kerja meningkat. Pertumbuhan Ekonomi dapat di artikan peningkatan output agregat atau pendapatan rill. Kedua peningkatan tersebut biasanya di hitung perkapita atau selama jangka waktu yang cukup panjang sebagai akibat peningkatan penggunaan input (Sunarto \& Sunyoto, 2016).

\section{Pajak Daerah}

Definisi pajak daerah merupakan iuran kepada negara yang dapat dipaksakan kepada wajib pajak untuk membayarnya menurut peraturan-peraturan, dengan tidak mendapat prestasi-kembali. Iuran ini ditujukan untuk digunakan membiayai pengeluaran-pengeluaran umum yang berhubungan dengan tugas negara untuk menyelenggarakan pemerintahan. Pengertian pajak menurut Sommerfeld dalam (Kresnandra \& Ni Made, 2013) ialah suatu pengalihan sumber-sumber yang wajib dilakukan dari sektor swasta kepada sektor pemerintah berdasarkan peraturan 
tanpa suatu imbalan kembali yang langsung dan seimbang. Pajak ini dimaksudkan agar pemerintah dapat melaksanakan tugas-tugasnya dalam menjalankan pemerintahan.

Berdasarkan Undang-Undang Nomor 28 tahun 2009 tentang Pajak Daerah dan Restribusi Daerah, yang dimaksud dengan Pajak Daerah, yang selanjutnya disebut Pajak merupakan kontribusi wajib kepada daerah yang terutang oleh orang pribadi atau badan yang bersifat memaksa berdasarkan Undang-Undang, dengan tidak mendapatkan imbalan secara langsung dan digunakan untuk keperluan daerah bagi sebesar-besarnya kemakmuran rakyat (Leasiwal, 2016).

Pajak daerah Kabupaten Aceh Utara harus ditingkatkan dalam proses pungutan nya baik itu dalam berupa jumlah besaran pajak yang diterima ataupun cara pungutan pajak yang harus dilakukan secara transparan seharusnya nilai besaran pajak yang diterima itu di publikasikan ke public karena ini merupakan pungutan dari masyarakat dan juga direktorat yang bersangkutan menjelaskan punggunaan nya untuk apa saja. Aceh Utara merupakan salah satu daerah yang sangat berpotensi untuk beberapa pendapatan pajak tertentu yaitu pajak reklame, pajak parkir dan pajak bumi dan bangunan karena daerah Aceh Utara merupakan daerah yang sedang digalakkan pembangunan seharusnya pendapatan pajak dari sektor ini dimaksimalkan.

\section{Retribusi Daerah}

Retribusi adalah pungutan yang dilakukan oleh pemerintah sehubungan dengan adanya suatu fasilitas jasa yang diberikan oleh pemerintah kepada pembayarnya. Menurut Sumitro dalam (Kusuma \& Wirawati, 2013) pengertian retribusi secara umum adalah pembayaranpembayaran kepada negara yang dilakukan oleh mereka yang menggunakan jasa-jasa negara.

Retribusi daerah juga dapat diartikan iuran kepada pemerintah yang dapat dipaksakan dan jasa balik secara langsung dapat ditunjuk. Paksaan disini bersifat ekonomis karena siapa saja yang tidak merasakan jasa balik pemerintah dia tidak dikenakan iuran itu.

Retribusi daerah pada umumnya merupakan sumber pendapatan penyumbang PAD kedua setelah pajak daerah. Bahkan untuk beberapa daerah penerimaan retribusi daerah ini lebih tinggi daripada pajak daerah. Retribusi daerah memiliki karakteristik yang berbeda dengan pajak daerah. Pajak daerah merupakan pungutan yang dilakukan pemerintah daerah kepada wajib pajak atas pembayaran pajak tersebut (Fatimah, 2010).

\section{Laba Badan Usaha Milik Daerah (BUMD)}

Badan Usaha Milik Daerah (BUMD) adalah perusahaan daerah yang didirikan dengan modal seluruh atau sebagian merupakan kekayaan daerah yang dipisahkan. Badan Usaha Milik Daerah (BUMD) merupakan salah satu sumber penerimaan dari sebuah pemerintahan daerah.

Sistem pembayaran atas jasa yang diserahkan oleh karyawan yang bekerja sebagai manajer, atau karyawan yang gajinya dibayarkan perbulan, tidak tergantung dari jam, hari kerja atau jumlah produk yang dihasilkan.

Sedangkan pengupahan adalah pembayaran atas penyerahan jasa yang dilakukan oleh karyawan pelaksanaan atau buruh yang upahnya dibayarkan berdasarkan dari jam, hari kerja, atau produk yang dihasilkan (Solihin, 2017).

BUMD merupakan badan usaha yang didirikan seluruhnya atau sebagian dengan modal daerah. Tujuan didirikan BUMD adalah dalam rangka menciptakan lapangan kerja atau mendorong pembangunan ekonomi daerah.

\section{Kerangka Konseptual}


Kerangka konseptual dalam penelitian ini dapat kita gambarkan sebagai berikut ini :

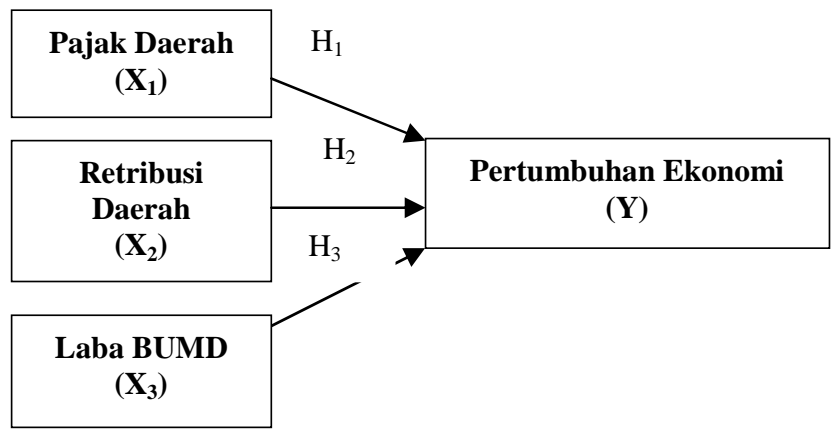

Gambar 2.1

Kerangka Konseptual

Kerangka konseptual mengambarkan pengaruh antara variabel bebas tehadap variabel terikat, yaitu pengaruh pajak daerah $\left(\mathrm{X}_{1}\right)$, retribusi daerah $\left(\mathrm{X}_{2}\right)$ dan laba BUMD $\left(\mathrm{X}_{3}\right)$ terhadap pertumbuhan ekonomi (Y) yang dibuktikan dengan uji F. dan secara parsial diduga terdapat pengaruh antara variabel pajak daerah $\left(\mathrm{X}_{1}\right)$, retribusi daerah $\left(\mathrm{X}_{2}\right)$ dan laba BUMD $\left(\mathrm{X}_{3}\right)$ terhadap pertumbuhan ekonomi $(\mathrm{Y})$.

\section{Hipotesis}

$\mathrm{H}_{1} \quad$ : Di duga Pajak Daerah berpengaruh positif dan signifikan terhadap Pertumbuhan Ekonomi di Kabupaten Aceh Utara.

$\mathrm{H}_{2}$ : Di duga Retribusi Daerah berpengaruh positif dan signifikan terhadap Pertumbuhan Ekonomi di Kabupaten Aceh Utara.

$\mathrm{H}_{3} \quad$ : Di duga Laba BUMD berpengaruh positif dan signifikan terhadap Pertumbuhan Ekonomi di Kabupaten Aceh Utara.

\section{METODE PENELITIAN}

\section{Objek dan Lokasi Penenelitian}

Objek penelitian meliputi Pajak Daerah, Retribusi daerah dan Laba BUMD di Kabupaten Aceh Utara sebagai variabel bebas dan Pertumbuhan Ekonomi di Kabupaten Aceh Utara sebagai variabel terikat. Adapun lokasi penelitian adalah di Kabupaten Aceh Utara.

\section{Jenis Data dan Sumber Data}

Jenis data yang akan dianalisis dalam penelitian ini adalah data kuantitatif, yaitu data sekunder selama periode 2005-2017 yang diperoleh dari berbagai instansi yang terkait yaitu BPS, Dinas Perindustrian dan sumber-sumber lainnya.

\section{Definisi Operasional Variabel}

Untuk menghindari kesalahan dalam mengartikan variabel yang dianalisis untuk membatasi problem dalam penelitian ini, perlu dijelaskan definisi operasional untuk masing-masing variabel. Adapun variabelvariabel penelitian yang akan di teliti dalam penelitian ini dapat di definisikan sebagai berikut:

1. Pertumbuhan Ekonomi (Y)

Pertumbuhan Ekonomi merupakan tingkat pertumbuhan ekonomi pada periode 2005-2017 atau besar nya persentase kenaikan atau penurunan pertumbuhan ekonomi di Kabupaten Aceh Utara Dan di ukur dalam satuan persen.

2. Pajak daerah $\left(X_{1}\right)$

Pajak Daerah merupakan kontribusi wajib kepada daerah yang terutang oleh orang pribadi atau badan yang bersifat memaksa berdasarkan Undang Undang, dengan tidak mendapat timbal balik secara langsung dan digunakan untuk keperluan daerah bagi sebesar-besarnya kemakmuran rakyat di Kabupaten Aceh Utara, dan di ukur dalam satuan milyar rupiah.

3. Retribusi Daerah $\left(\mathrm{X}_{2}\right)$

Retribusi adalah pungutan yang dilakukan oleh pemerintah Aceh Utara sehubungan dengan adanya suatu fasilitas jasa yang diberikan oleh pemerintah kepada masyarakat kabupaten Aceh Utara dalam satuan milyar rupiah.

4. Laba BUMD $\left(\mathrm{X}_{3}\right)$

Laba BUMD merupakan laba yang dihasilkan perusahaan BUMD Aceh 
Utara selama periode tahun 2005-2017 yang diukur dalam satuan juta rupiah.

\section{Analisis Regresi}

Analisis yang digunakan dalam penelitian ini adalah analisis regresi linear berganda yang menggunakan metode OLS (Ordinary Least Square). Dengan menggunakan program Eviews 10. Model regresi berganda merupakan suatu model regresi yang terdiri dari satu variable Independen. Bentuk umum regresi linear berganda dapat ditulis sebagai berikut:

$\mathrm{Y}=\beta_{0}+\beta_{1} \operatorname{Ln} X_{1}+\beta_{2} \operatorname{LnX} X_{2}+\beta_{3} \operatorname{Ln} X_{3}+e$ Keterangan:

LnY = Pertumbuhan Ekonomi

$\boldsymbol{\beta}_{0}, \alpha=$ Konstanta

$\beta_{1}, \beta_{2}=$ Koefisien Regresi

$\operatorname{LnX}_{1}=$ Pajak Daerah

$\mathrm{LnX}_{2}=$ Retribusi Daerah

$\mathrm{LnX}_{3}=$ Laba BUMD

$\mathrm{e}=$ Error term, yaitu tingkat kesalahan dalam penelitian ini.

\section{Hasil Uji Normalitas}

Menurut Gujarati (2009) menyebutkan bahwa uji normalitas adalah suatu pengujian dimana jika probabilitasnya lebih besar dari pada alpha 5 persen maka uji normalitas diterima. Justifikasi lainnya untuk uji ini adalah dengan membandingkan nilai $\mathrm{J}-\mathrm{B}$ hitung dengan $\chi^{2}$ tabel, apabila J-B hitung $<\chi^{2}$ tabel maka residual terdistribusi normal. Sedangkan menurut Sunyoto (2011) Uji normalitas adalah pengujian yang akan menguji data variabel bebas (X) dan data variabel terikat $(\mathrm{Y})$ pada persamaan regresi yang dihasilkan berdistribusi normal atau berdistribusi tidak normal. Berikut adalah hasil pengolahan data:

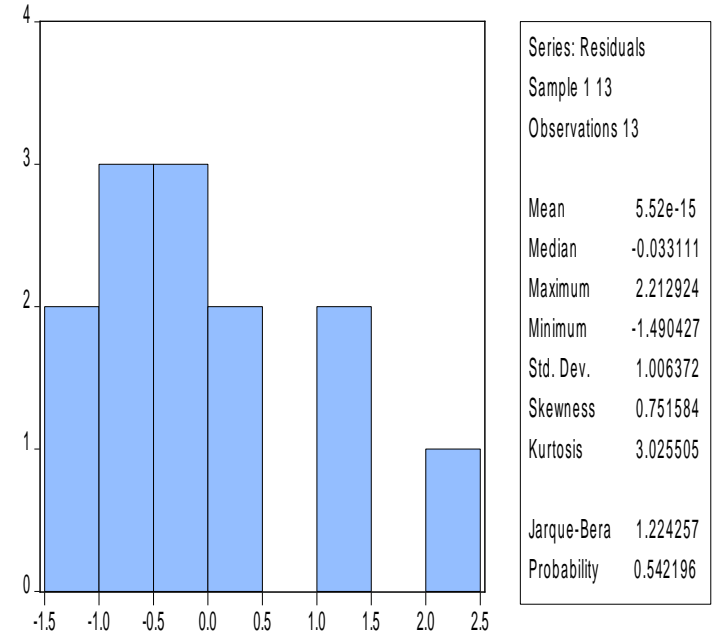

Gambar 4.9 : Hasil Uji Normalitas Data

Sumber : Hasil Pengolahan Data 2019

Berdasarkan hasil pengujian yang tampak pada tabel di atas nilai JarqueBera adalah sebesar 0,122, sementara nilai Chi Square dengan melihat jumlah variabel bebas yang kita pakai dalam hal ini 3 variabel bebas dan nilai signifikan yang kita pakai dalam hal ini 0,05 (5\%), di dapat nilai Chi Square sebesar 7.81 yang berarti nilai Jarque-Bera lebih kecil dari nilai Chi Square $(0,1224<7.81)$ dan Probabilitas sebesar 0,542>0,05. Artinya Pajak daerah, Retribusi Daerah dan Laba BUMD serta Pertumbuhan Ekonomi di Kabupaten Aceh Utara sebesar 0,542 lebih besar dari 0,05, maka dapat disimpulkan bahwa data residual dalam penelitian ini sudah berdistribusi normal.

\section{Uji Asumsi Klasik}

\section{Hasil Uji Autokorelasi}

Menurut Ghozali (2006) uji autokolerasi bertujuan untuk menguji apakah model regresi linear ada kolerasi antara kesalahan pengganggu pada periode $\mathrm{t}$ dengan kesalahan pengganggu pada periode t-1 (sebelum), jika terjadi korelasi, maka dinamakan ada masalah autokorelasi. Autokorelasi dapat terjadi karena observasi yang berurutan sepanjang waktu berkaitan satu sama lainnya. Masalah ini timbul karena residual (kesalahan pengggangu) tidak bebas dari runtut waktu (time series) karena gangguan pada seorang individu/kelompok cenderung berpengaruh terhadap 
individu/kelompok yang sama pada periode berikutnya. Ada beberapa cara yang dapat digunakan untuk melihat terjadi atau tidaknya autokolerasi. Salah satunya dengan Uji Breusch-Godfrey Serial Correlation LM Test:

\section{Tabel 4.3}

\section{Hasil Uji Breusch-Godfrey Serial} Correlation LM Test

\begin{tabular}{|c|c|c|c|}
\hline \multicolumn{3}{|c|}{ Breusch-Godfrey Serial Correlation LM Test: } & \multirow[b]{2}{*}{0.8993} \\
\hline F-statistic & 0.107762 & Prob. $F(2,7)$ & \\
\hline $\begin{array}{l}\text { Obs*R- } \\
\text { squared }\end{array}$ & 0.388303 & $\begin{array}{l}\text { Prob. Chi- } \\
\text { Square(2) }\end{array}$ & 0.8235 \\
\hline
\end{tabular}

Sumber: Hasil Olah Data, 2019.

Berdasarkan Uji LM Test dari df ChiSquare pada $\alpha=1 \%$ dan $\alpha=5 \%$ masingmasing adalah 11.34 dan 5.99. Hasil dari Obs*R-squared adalah sebesar 0,39 atau $0,39<5.99$ dan Probabilitas Chi-Squared sebesar 0,82 >0,05. Yang berarti bahwa penelitian ini sudah terbebas dari indikasi autokorelasi.

\section{Hasil Uji Multikolinieritas}

Multikolinieritas ialah melihat hubungan antara variabel bebas yang satu dengan variabel bebas lainnya. Seperti pada tabel dibawah ini.

Tabel 2

Hasil Uji Multikolinieritas

\begin{tabular}{|c|r|r|r|}
\hline \multicolumn{2}{|c|}{ Correlation } & \multicolumn{1}{l|}{} & \\
\hline t-Statistic & PE & LPD & LNRD \\
\hline PE & 1.000 .000 & & \\
\hline & ----- & & \\
\hline & & & \\
\hline LPD & 0.415883 & 1.000 .000 & \\
\hline & 1.516 .714 & ----- & \\
\hline & & & \\
\hline LNRD & 0.295234 & 0.328117 & 1.000 .000 \\
\hline & 1.024 .864 & 1.152 .019 & ---- \\
\hline & & & \\
\hline LNBUMD & 0.823284 & 0.808220 & 0.411745 \\
\hline & 4.810 .394 & 4.551 .954 & 1.498 .525 \\
\hline
\end{tabular}

Sumber: Hasil Olah Data, 2019

Berdasarkan tabel diatas terlihat bahwa koefisien korelasi sebesar 0.42 antara PD dengan PE atau sebaliknya, dan 0.808 antara PD dengan LBUMD atau sebaliknya dan 0.41 antara $\mathrm{RD}$ dengan LBUMD atau sebaliknya berarti dapat kita simpulkan bahwa $(0.42,0.808,0.41<0.9)$, karena koefisien korelasinya lebih kecil dari 0.9. Hal ini menunjukkan tidak terjadinya multikolinieritas.

\section{Hasil Uji Heteroskedastisitas}

Heteroskedasitas merupakan hasil yang perlu diperhatikan dari uji ini ialah $\mathrm{F}$ dan Obs*R-Squared, jika nilai probabilitas lebih besar alpha (0.05), seperti yang terdapat pada tabel di bawah ini :

Tabel 3

Hasil Uji Heteroskedastisitas

\begin{tabular}{|l|l|l|c|}
\hline \multicolumn{3}{|l|}{ Heteroskedasticity Test: White } & \\
\hline F-statistic & 1.740 .454 & Prob. F(3,9) & 0.2282 \\
\hline Obs*R-squared & 4.772 .939 & $\begin{array}{l}\text { Prob. Chi- } \\
\text { Square(3) }\end{array}$ & 0.1892 \\
\hline $\begin{array}{l}\text { Scaled explained } \\
\text { SS }\end{array}$ & 2.316 .794 & $\begin{array}{l}\text { Prob. Chi- } \\
\text { Square(3) }\end{array}$ & 0.5093 \\
\hline
\end{tabular}

Sumber: Hasil Olah Data tahun, 2019.

Berdasarkan hasil uji white-Test menggunakan program eviews versi 9, dapat dilihat nilai Obs* $\mathrm{R}$ sebesar 4.77 dengan $\chi^{2}$ dengan df (3) pada $\chi^{2}$ pada tabel $\alpha: 5 \%$ sebesar 7.81. Berdasarkan hasil Obs*R.squared $4.77<7.81$, Hal ini juga dilihat dari probabilitas sebesar $0,189>$ 0,05. maka dalam model penelitian ini sudah tidak ada indikasi heterosdaktisitas.

\section{Hasil Uji Liniear Berganda}

Analisis yang digunakan dalam penelitian ini adalah analisis regresi linear berganda yang menggunakan metode OLS (ordinary least square), dengan menggunakan program Eviews 9, model regresi berganda merupakan suatu model regresi yang terdiri dari satu variabel Independen. hasil regresi linear berganda yang dilakukan adalah sebagai berikut :

\section{Tabel 4}

Hasil Uji Liniear Berganda

\begin{tabular}{|l|r|r|r|r|}
\hline \multicolumn{1}{|c|}{ Variable } & Coefficient & Std. Error & t-Statistic & Prob. \\
\hline C & -5.626 .546 & 1.344 .269 & 4.185 .579 & 0.0024 \\
\hline LNPD & -3.230 .959 & 0.950120 & 3.400 .580 & 0.0079 \\
\hline & & & & \\
LNRD & -0.036380 & 0.087780 & -0.414442 & 0.6883 \\
\hline
\end{tabular}




\begin{tabular}{|l|c|c|c|r|} 
LNBUMD & 5.865 .281 & 0.901303 & 6.507 .558 & 0.0001 \\
\hline R-squared & 0.859993 & \multicolumn{2}{|l|}{} \\
\hline $\begin{array}{l}\text { Adjusted R- } \\
\text { squared }\end{array}$ & 0.813324 & & \\
\hline F-statistic & 1.842 .754 & Durbin-Watson stat & 1.699 .284 \\
\hline $\begin{array}{l}\text { Prob(F- } \\
\text { statistic) }\end{array}$ & 0.000350 & & & \\
\hline
\end{tabular}

Sumber: Hasil Olah Data tahun, 2019

Model dasar penelitian adalah : $\mathrm{Yt}=\beta_{0}+$ $\beta_{1} \operatorname{Ln} X_{1 \mathrm{t}}+\beta_{2} \operatorname{Ln} X_{2 \mathrm{t}}+\beta_{3} \operatorname{Ln} X_{3 \mathrm{t}}+\mathrm{et}$,

Atau, $\quad$ PEt $=\beta_{0}+\beta_{1} \operatorname{LnPD}_{\mathrm{t}}+\beta_{2} \mathrm{LnRD}_{\mathrm{t}}+$ $\beta_{3}$ LnBUMD $_{t}+$ et,dan hasilnya adalah: PEt $=-56.27-3.23$ LnPDt -0.36 LnRDt, + 5.87 LnBUMDt

yaitu dimana :

Konstanta $=\mathbf{- 5 6 . 2 7}$,

Apabila Pajak Daerah, Retribusi Daerah dan Laba BUMD bernilai konstan maka Pertumbuhan Ekonomi juga akan konstan sebesar -56.27 persen.

Pajak Daerah sebesar -3.23.

Apabila Pajak Daerah meningkat sebesar 1\% maka Pertumbuhan Ekonomi akan menurun sebesar $3.23 \%$, dengan asumsi retribusi daerah dan Laba BUMD Konstan. Retribusi Daerah sebesar -0.036.

Apabila Retribusi Daerah meningkat sebesar 1\% maka Pertumbuhan Ekonomi akan menurun sebesar $0.04 \%$, dengan asumsi pajak daerah dan Laba BUMD konstan.

Laba BUMD sebesar 5.87.

Apabila Laba BUMD meningkat sebesar 1\% maka Pertumbuhan Ekonomi akan meningkat sebesar 5.86 persen, dengan asumsi pajak daerah dan retribusi daerah konstan.

\section{Pembuktian Hipotesis \\ Hasil Uji t}

Pengujian ini dilakukan dengan cara membandingkan $t_{\text {statistik }}$ pada hasil regresi dengan $t_{\text {tabel }}$.

1. Jika $t_{\text {hitung }}>t_{\text {tabel, }}$ pada $\alpha=0.05$ maka $H_{1}$ diterima yang artinya variabel penjelas secara individual mempengaruhi variabel yang dijelaskan secara signifikan.

2. Jika $t_{\text {hitung }}<t_{\text {tabel, }}$ pada $\alpha=0.05$ maka $\mathrm{H}_{1}$ ditolak yang artinya variabel penjelas secara individual tidak mempengaruhi variabel yang dijelaskan secara signifikan.

Uji parsial di peroleh dengan melihat $t_{\text {tabel }}$ pada $\alpha=1 \%$, adalah $(\mathrm{n}-\mathrm{k})=17-4=$ $13=-3.01$ dan pada $\alpha=10 \%$, adalah sebesar $=1.77$. Berdasarkan tabel $4.6 \mathrm{di}$ atas dapat dilihat yaitu :

Konstanta sebesar -4.19 . oleh karena $\mathrm{t}_{\text {hitung }}>\mathrm{t}_{\text {tabel }}$ atau $-4.19<-3.01$, maka terima $\mathrm{H} 0$ dan tolak Ha, yang berarti pajak daerah, retribusi daerah dan Laba BUMD berpengaruh secara signifikan dan negatif terhadap pertumbuhan ekonomi. Hal ini juga bisa dilihat dari probabilitas $0.0024<$ 0.01 .

Variabel Pajak Daerah memiliki nilai $t_{\text {hitung }}>t_{\text {tabel }}$ atau $-3.40>-3.01$, maka tolak $\mathrm{H} 0$ dan terima $\mathrm{H}_{1}$, artinya Pajak Daerah berpengaruh secara negatif terhadap Pertumbuhan Ekonomi di Kabupaten Aceh Utara. Hal ini juga dapat dilihat dari probabilitas $0.0079<0.01$.

Selanjutnya variabel Retribusi Daerah memiliki nilai $t_{\text {hitung }}<\mathrm{t}_{\text {tabel }}$ atau $-0.414<-$ 1.77, maka terima $\mathrm{H} 0$ dan tolak $\mathrm{H}_{2}$, artinya Retribusi Daerah tidak berpengaruh secara signifikan dan negatif terhadap Pertumbuhan Ekonomi di Kabupaten Aceh Utara. Hal ini juga bisa dilihat dari probabilitas $0.69>0.1$.

Kemudian Laba BUMD memiliki nilai $t_{\text {hitung }}>\mathrm{t}_{\text {tabel }}$ atau $6.50>3.01$, maka tolak $\mathrm{H} 0$ dan terima $\mathrm{H}_{3}$, artinya Laba BUMD berpengaruh terhadap Pertumbuhan Ekonomi di Kabupaten Aceh Utara. Hal ini juga dapat dilihat dari probabilitas $0.0001<0.01$.

\section{Hasil Uji F}

Uji $F$ dilakukan untuk melihat pengaruh variabel bebas terhadap variabel terikat secara bersama-sama dengan membandingkan antara $F_{\text {hitung }}$ dengan $F_{\text {tabel, }}$ apabila $F_{\text {hitung }}>F_{\text {tabel, }}$ dengan cara df (k$1)(4-1)=3(n-k)=(13-4)=9(3)(9)=6.99$ : jadi variabel Pajak Daerah, Retribusi Daerah dan Laba BUMD secara bersama- 
sama berpengaruh signifikan dan positif terhadap Pertumbuhan Ekonomi karena nilai sebesar $18.42>6.99$. Hal ini juga bisa dilihat dari nilai probabilitas ( $\mathrm{P}$-value) sebesar $0.00<0,01$.

Berdasarkan hasil pengujian yang dilakukan secara serempak atau bersamasama dari tabel diatas maka dapat dilihat nilai $F_{\text {hitung }}$ sebesar 18.42 lebih besar dari pada $F_{\text {tabel }}$ yaitu sebesar 6.99, artinya variabel Pajak Daerah, Retribusi Daerah dan Laba BUMD berpengaruh secara bersama-sama terhadap variabel Pertumbuhan Ekonomi di Kabupaten Aceh Utara.

\section{Koefisien Determinasi $\left(\mathbf{R}^{2}\right)$ dan Koefisen Korelasi (R)}

\section{Koefisien Determinasi $\left(\mathbf{R}^{\mathbf{2}}\right)$}

Koefisien determinasi ini mengukur seberapa jauh kemampuan model dalam menerangkan variasi variabel dependen (uji goodness of fit). Koefisien ini nilainya antara 0 (nol) sampai dengan 1 (satu), semakin besar nilai koefisien tersebut maka variabel-variabel independen lebih mampu menjelaskan variasi variabel dependen. Nilai koefisien determinasi merupakan suatu ukuran yang menunjukkan besar sumbangan dari variabel independen terhadap variabel dependen, atau dengan kata lain koefisien determinasi mengukur variasi turunan $\mathrm{Y}$ yang diterangkan oleh pengaruh linier $X$. Bila nilai koefisien determinasi yang diberi simbol R2 mendekati angka 1, maka variabel independen makin mendekati hubungan dengan variabel dependen, sehingga dapat dikatakan bahwa pengaruh model tersebut dapat di benarkan (Gujarati, 2009).

Dari hasil pengolahan data R.Squared sebesar 0.8133 jadi besarnya pengaruh Pajak Daerah, Retribusi Daerah dan Laba BUMD terhadap Pertumbuhan Ekonomi di Kabupaten Aceh Utara adalah sebesar 0.8133 (81.33\%), dan sisanya 0,1802
(18.02\%) dipengaruhi oleh variabel lain diluar model ini.

\section{Koefisen Korelasi (R)}

Menurut Supranto (2009) analisis korelasi merupakan suatu cara untuk mengetahui kuat atau tidaknya hubungan antara variabel independen (X) dan variabel dependen (Y), apabila dinyatakan dengan fungsi linear dan di ukur dengan suatu nilai yang disebut koefisien korelasi.

Berdasarkan hasil pengolahan data pada tabel 4.8 diperoleh nilai korelasi (R) $=\sqrt{ } \mathrm{R}^{2}=\sqrt{ } 0.859999=0.93$. Jadi hubungan variabel Pajak Daerah, Retribusi Daerah dan Laba BUMD terhadap Pertumbuhan Ekonomi berhubungan sangat erat/sangat kuat secara positif, karena nilai 0,93 mendekati positif satu (+1), Atau hubungan variabel Pajak Daerah, Retribusi Daerah dan Laba BUMD terhadap Pertumbuhan Ekonomi sangat kuat secara positif.

\section{Pembahasan}

\section{Hubungan antara Pajak Daerah dengan Pertumbuhan Ekonomi}

Berdasarkan pengujian secara parsial dapat disimpulkan bahwa variabel Pajak Daerah berpengaruh negatif dan signifikan terhadap Pertumbuhan Ekonomi di Kabupaten Aceh Utara. Hal ini tidak sesuai dengan penelitian sebelumnya yang dilakukan oleh Fitriyati (2013) Hasil dari pengujian statistik dalam penelitian ini menunjukkan bahwa secara simultan pajak daerah, retribusi daerah, dan DAK berpengaruh signifikan terhadap pertumbuhan ekonomi daerah. Secara parsial pajak daerah berpengaruh positif dan siginifikan terhadap pertumbuhan ekonomi daerah. Hal ini menunjukkan bahwa hubungan antara pajak daerah dengan pertumbuhan ekonomi berhubungan positif yaitu apabila pajak daerah meningkat maka akan meningkatkan pertumbuhan ekonomi, ataupun sebaliknya, apabila pajak daerah menurun maka akan menurunkan 
pertumbuhan ekonomi di kabupaten Aceh Utara.

\section{Hubungan antara Retribusi Daerah dengan Pertumbuhan Ekonomi}

Berdasarkan pengujian secara parsial dapat disimpulkan bahwa Retribusi Daerah tidak berpengaruh positif dan signifikan terhadap Pertumbuhan Ekonomi di Kabupaten Aceh Utara. Hal ini sesuai dengan penelitian yang dilaukan oleh (Hermawan, 2016) Pengaruh Pajak Daerah Dan Retribusi Daerah Terhadap Pertumbuhan Ekonomi, Kemiskinan, Dan Pengangguran. Hasil dari penelitian ini menunjukkan bahwa baik dari persamaan tahun dasar maupun lag satu tahun, pajak daerah dan retribusi daerah tidak berpengaruh secara signifikan terhadap pertumbuhan ekonomi. mengatakan bahwa Retribusi Daerah berpengaruh terhadap Pertumbuhan Ekonomi. Hubungan antara retribusi daerah dengan pertumbuhan ekonomi adalah berhubungan negatif.

\section{Hubungan antara Laba BUMD dengan Pertumbuhan Ekonomi}

Selanjutnya untuk mengetahui hubungan dari variabel Pajak Daerah, Retribusi Daerah dan Laba BUMD terhadap Pertumbuhan Ekonomi di Kabupaten Aceh Utara dapat dilihat pada nilai $\mathrm{R}^{2}$. Dari hasil pengujian ditemukan bahwa nilai $\mathrm{R}^{2}$ sebesar 0.9018 yang berarti pengaruh Pajak Daerah, Retribusi Daerah dan Laba BUMD terhadap Pertumbuhan Ekonomi di Kabupaten Aceh Utara adalah sebesar 0.9018 atau $90.18 \%$, sementara sisanya sebesar $0.0982 \quad(9.82 \%)$ dipengaruhi oleh variabel lainnya di luar penelitian ini.

Berdasarkan hasil empat pengujian Asumsi Klasik, diketahui bahwa Uji Normalitas, Uji Autokorelasi, Uji Heteroskedastisitas, dan Uji Multikoliniearitas menunjukkan bahwa data dapat di analisis kedalam persamaan regresi di karenakan tidak terjadi masalah pada semua Uji Asumsi Klasik. Untuk mengetahui pengaruh variabel Pajak
Daerah, Retribusi Daerah dan Laba BUMD terhadap Pertumbuhan Ekonomi di Kabupaten Aceh Utara dapat di lihat dari nilai R. Berdasarkan hasil pengujian ditemukan bahwa nilai $\mathrm{R}$ sebesar 0.8133 yang berarti terdapat hubungan yang erat antara variabel Pajak Daerah, Retribusi Daerah dan Laba BUMD terhadap Pertumbuhan Ekonomi di Kabupaten Aceh Utara.

Berdasarkan pengujian secara parsial dapat di ambil kesimpulan bahwa Laba BUMD berpengaruh terhadap Pertumbuhan Ekonomi. Hal ini sesuai dengan penelitian yang di lakukan oleh (Anggraini, 2017) Hasil penelitian menunjukkan bahwa, secara statistik membuktikan bahwa pajak daerah, retribusi daerah, dan hasil laba BUMD berpengaruh baik secara simultan maupun secara parsial terhadap PAD Kota Surabaya, dengan meningkatnya PAD sehingga akan meningkatkan pertumbuhan ekonomi Surabaya.

Berdasarkan hasil pengujian yang dilakukan secara serempak atau bersamasama dapat disimpulkan bahwa variabel Pajak Daerah, Retribusi Daerah dan Laba BUMD berpengaruh secara simultan terhadap Pertumbuhan Ekonomi di Kabupaten Aceh Utara.

\section{KESIMPULAN DAN SARAN Kesimpulan}

Berdasarkan hasil penelitian yang telah dilakukan maka dapat diperoleh beberapa kesimpulan sebagai berikut :

a. Hasil penelitian secara parsial menunjukkan bahwa pajak daerah berpengaruh negatif dan signifikan terhadap pertumbuhan ekonomi di Kabupaten Aceh Utara, karena jika pajak daerah meningkat akan menurunkan pertumbuhan ekonomi.

b. Hasil penelitian secara parsial menunjukkan bahwa retribusi daerah tidak berpengaruh dan negatif terhadap pertumbuhan ekonomi di Kabupaten Aceh Utara, secara teori 
sudah sesuai dan hasilnya tidak berpengaruh.

c. Hasil penelitian secara parsial menunjukkan bahwa Laba BUMD berpengaruh positif dan signifikan terhadap pertumbuhan ekonomi di Kabupaten Aceh Utara.

d. Berdasarkan hasil pengujian yang dilakukan secara serempak atau bersama-sama diketahui bahwa Pajak Daerah, Retribusi Daerah dan Laba BUMD berpengaruh secara simultan terhadap Pertumbuhan Ekonomi di Kabupaten Aceh Utara sebesar 0.8133 (8133\%).

\section{Saran}

Berdasarkan hasil penelitian yang telah dilakukan oleh peneliti terdapat beberapa saran, yaitu :

a. Dengan menggunakan variabel yang sama penelitian selanjutnya dapat dilakukan pada semua kabupaten dan kota diseluruh Indonesia. Hal ini bertujuan untuk memiliki cakupan yang lebih luas dan tidak hanya sebagian atau kota saja.

b. Bagi Pemerintah Kabupaten Aceh Utara agar dapat lebih memaksimalkan dalam upaya meningkatkan pertumbuhan ekonomi, karena semakin tinggi pertumbuhan ekonomi akan memberikan efek positif terhadap kemajuan Kabupaten Aceh Utara.

c. Pemerintah seharusnya menggali potensi baru serta memaksimalkan agar terciptanya lapangan kerja baru sehingga dapat meningkatkan penyerapan tenaga kerja yang dapat meningkatkan pertumbuhan ekonomi di Kabupaten Aceh Utara.

\section{KEPUSTAKAAN}

Anggraini (2017). Pengaruh Pajak Daerah dan Hasil Laba BUMD Terhadap Pendapatan Asli
Daerah (PAD) Kota Surabaya, 3, 854-866.

Badan Pusat Statistik (2016) Laporan Aceh Utara Dalam Angka Tahun 2007-2016. ht tp ac eh ut a ra ka b. s . eh ut a ka b. (n.d.).

Fitriyati Is, F. (2013). Peranan Pajak Daerah Dan Retribusi Daerah Pada Dinas Pendapatan Pengelolaan Keuangan Dan Aset Kabupaten Rokan Hulu, 2(1), 59-71.

Ginting (2016). Pengaruh Retribusi Daerah dan Laba BUMD Terhadap Pertumbuhan Ekonomi di Sulawei Barat., 164.

Gujarati (2009). Pengaruh Pajak Reklame dan Pajak Penerangan Jalan terhadap Pertumbuhan Ekonomi. Jurnal Kajian Ekonomi dan Studi Pembangunan Volume I No. 3,U., Desember 2014.

Hotman (2013). Analisis Dampak Pajak

Daerah Terhadap

Pertumbuhan Ekonomi di Sulawesi Utara. Tahun Anggaran 2013: Analisis Dampak Pajak Daerah.

Kresnandra (2013). Pengaruh Pajak Daerah Dan Retribusi Daerah Terhadap Tingkat Pengangguran Dengan Belanja Modal Sebagai Variabel Pemoderasi. Jurna Ekonomi, 3(sjddadkadakd), 544-560.

Kurniawan (2010).

Pengaruh

Penerimaan Pajak dan

Retribusi Daerah Terhadap Peningkatan Pendapatan Asli Daerah. 311-29.

Kusuma (2013). Analisis Pengaruh Penerimaan Pajak Daerah dan Retribusi Daerah Terhadap Peningkatan PAD Sekabupaten/Kota di Provinsi Bali. E-Jurnal, Fakultas Ekonomi Dan Bisnis, Universitas Udayana, 5(3), 574-585.

Leasiwal (2016). Pengaruh Investasi 
Pemerintah, Pemerintah, Retribusi Pertumbuhan

$$
\begin{array}{rr}
\text { Konsumsi } \\
\text { Pajak dan }
\end{array}
$$
Terhadap

Provinsi Maluku. Jurnal Ekonomi, X(1), 69-81.

M. Yanis (2018). Analisis Retribusi Daerah dan Laba BUMD Terhadap Pertumbuhan Ekonomi Banten. Fakultas Ekonomi dan Bisnis, 1, 6, 16951722.

Ma`ruf, A., \& Wihastuti, L. (2008). Analisis Pertumbuhan Ekonomi Indonesia. : Determinan dan Prospeknya. Ekonomi Dan Studi Pembangunan, 9(1), 44-55.

Rori (2016). Analisis Pengaruh Pendapatan Asli Daerah ( PAD ) Terhadap Pertumbuhan Ekonomi Di Provinsi Sulawesi Utara Tahun 2001-2013. Jurnal Berkala Ilmiah Efisiensi, 16(2), 243-254.

Sutrisno (2017). Analisis Tingkat

Partisipasi Angkatan Kerja (Tpak) Terhadap Pertumbuhan Ekonomi Kabupaten Di Provinsi Riau. MediaTrend,12(1),76.

https://doi.org/10.21107/mediatre nd.v12i1.2541

Sunarto, \& Sunyoto (2016). Pengaruh Pajak Daerah dan Retribusi Daerah Terhadap Kemandirian Daerah yang Berdampak pada Pertumbuhan Ekonomi Daerah. Jurnal Ekonomi, (43), 13-22.

Vivi (2016). Pengaruh Investasi dan Laba BUMD Terhadap Pertumbuhan Ekonomi Jawa Barat.89-12

Walewangko (2017). Pengaruh pajak Daerah, Laba BUMD dan Reribusi Daerah Terhadap Pertumbuhan Ekonomi di Kabupaten Jember. 17(2), 4859.
Wirawati (2016). Pengaruh Laba BUMD Terhadap Pertumbuha Ekonomi Provinsi-Provinsi di Indonesia Sebelum dan Sesudah Otonomi Daerah, 111-123.

Yasin (2015). Pengaruh Laba BUMD dan Pajak Daerah Terhadap Pendapatan Asli Daerah di Jawa Timur. $\{$ Title $\}, 7(2), 45-$ 461. 